> where rain could allow mosquito eggs to hatch. In countries such as Italy, where the tiger mosquito is already widespread, surveillance is instead geared more towards keeping numbers under control.

VBORNET's geographical information system allows scientists to combine surveillance data with environmental factors, including temperature and humidity, to better track the main invasive mosquito species. Models based on these combined data can reveal, for example, how environmental conditions can affect mosquitoes' ability to transmit pathogens, and so provide information on the likelihood of outbreaks in various regions.

The maps may also perform a useful peerpressure function, says Braks, by highlighting where researchers and authorities have failed to supply and share data. "What we hope is that no one will want to be a blank on the map." -

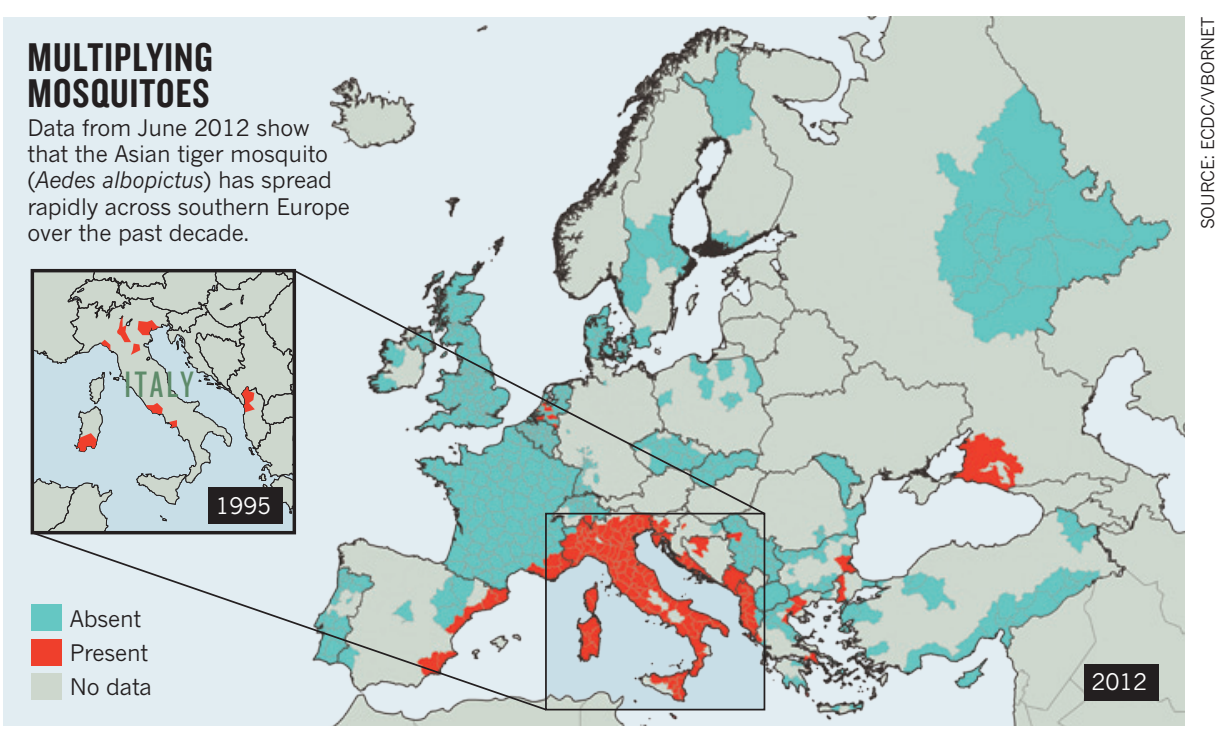

\title{
EU battles over research billions
}

\section{Politicians will spend the next few months negotiating cuts to Horizon 2020's budget.}

\section{BY NATASHA GILBERT}

$\mathrm{T}$

Tens of billions of euros are at stake as negotiations ramp up to shape Europe's next seven-year research programme. The discussions will cover familiar divisions over applied versus basic research and conflicting national agendas, but the continent's ongoing financial problems will add an extra measure of anxiety.

The European Commission proposed the general size and shape of the Horizon 2020 research and innovation programme in November 2011 (see Nature http://doi.org/ dtvtbx; 2011). European Union (EU) member states and members of the European Parliament will negotiate and agree on the budget and final details of the programme, which will run from 2014 to 2020 , over the next 15 months.

Last year, the commission requested $€ 77.6$ billion (US\$99 billion) for Horizon 2020, out of a total European budget for 2014-20 of about $€ 1$ trillion (at constant 2011 prices). But many members of the European Parliament (MEPs) want research to get $€ 100$ billion, twice as much as was allocated to Horizon 2020's predecessor, the Seventh Framework Programme (FP7), which runs from 2007 until 2013 (see 'Budget breakdown'). Most scientists and EU science officials say that such a large jump is unrealistic, and there are growing fears that even the lower budget proposed by the commission is unlikely, given Europe's shaky economy.

\section{BUDGET BREAKDOWN}

The proposed budget for Europe's Horizon 2020 research-funding programme, the successor to its Seventh Framework Programme, would boost the European Research Council (ERC), the Marie Curie Actions career-development programme and the European Institute of Innovation and Technology (EIT).

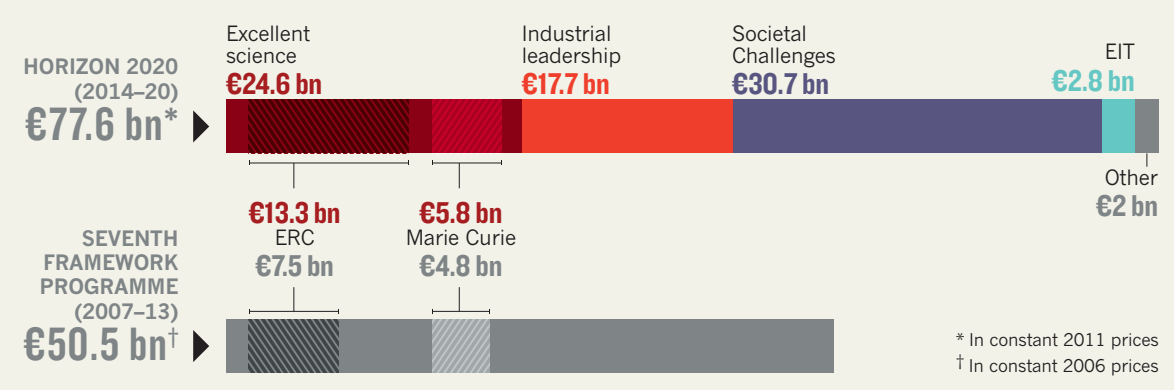

At a meeting on 30 August, high-level ministers said that cuts to the proposed EU budget are "inevitable", implying that spending on Horizon 2020 will be eroded. Ministers are aiming to reach a consensus on the size and shape of the EU budget by the end of the year, but in the meantime, MEPs, scientists and member-state officials will fight over which of Horizon 2020's ambitions should bear the brunt of any budget reductions. The first sortie will come on 17-18 September, when MEPs on the European Parliament's Industry, Research and Energy (ITRE) committee will begin discussing around 3,000 suggested amendments to the Horizon 2020 budget.

Most likely to feel the pinch is the European Institute of Innovation and Technology (EIT), a virtual institute headquartered in Budapest and made up of scientific 'communities' that conduct research on themes such as climate change and sustainable energy. The institute also runs postgraduate education programmes and knowledge-transfer activities to disseminate the fruits of research to businesses and policy-makers (see Nature 440, 8-9; 2006). The EIT concept was developed and championed by the European Commission, which now suggests that the institute's budget should win $€ 2.8$ billion from Horizon 2020, 3.6\% of the total research budget and vastly more than the $€ 309$ million in European funds allocated to it between 2008 and 2013.

However, few outside the commission want the EIT to claim so much; some argue that the 
崖 institute has yet to prove its scientific worth. Teresa Madurell, a Spanish social-democrat MEP on the ITRE committee, suggests that the EIT should get no more than $3.1 \%$ of Horizon 2020's funds. Paul Rübig, an Austrian Christian Democrat MEP who also sits on the committee, wants to trim that even further, suggesting that the EIT's remit be reduced to knowledge-transfer activities only.

The EIT's critics say that the money would be better spent on initiatives with a proven track record. The most popular programmes include the European Research Council (ERC), which dispenses excellence-based grants for frontier science, and the Marie Curie Actions programme, which provides career-development grants to young researchers. The commission proposed that the ERC's budget should rise by $77 \%$ to $€ 13.3$ billion, but Luke Georghiou, who studies European research policy at the University of Manchester, UK, expects opposition from member states in eastern Europe, which could hold up the budget negotiations. Scientists in those countries often lose out to those from research powerhouses such as the United Kingdom and Germany when ERC grants are allocated. Some say that the ERC should also fund those scientists with the 'potential for excellence. Vicky Ford, a British Conservative member of the ITRE committee, counters that ERC funding should go only to excellent research.

The ERC tends to fund individual researchers, so during FP7 larger collaborations have relied on separate funding streams. But some scientists are concerned that funding for applied research has squeezed out support for basic science in these programmes. Over the past four years, calls for collaborative proposals in areas of basic science such as epigenetics and protein regulation have become less frequent, says Karin Metzlaff, executive director of the European Plant Science Organisation in Brussels. She hopes that the ITRE committee meeting can help to make basic-science projects a bigger priority in Horizon 2020's collaborativeresearch programme, dubbed Societal Challenges.

Overall, research is likely to be spared the EU budget's most severe cuts, because politicians recognize that investing in science is central to boosting economic growth. Indeed, countries such as Spain, which has slashed domestic science spending owing to the financial crisis, will become more reliant on Horizon 2020 funds. That may even prompt them to give ground in negotiations on contentious issues such as human embryonic stem-cell research, says Georghiou. "They need to replace their national funding shortage," he says.

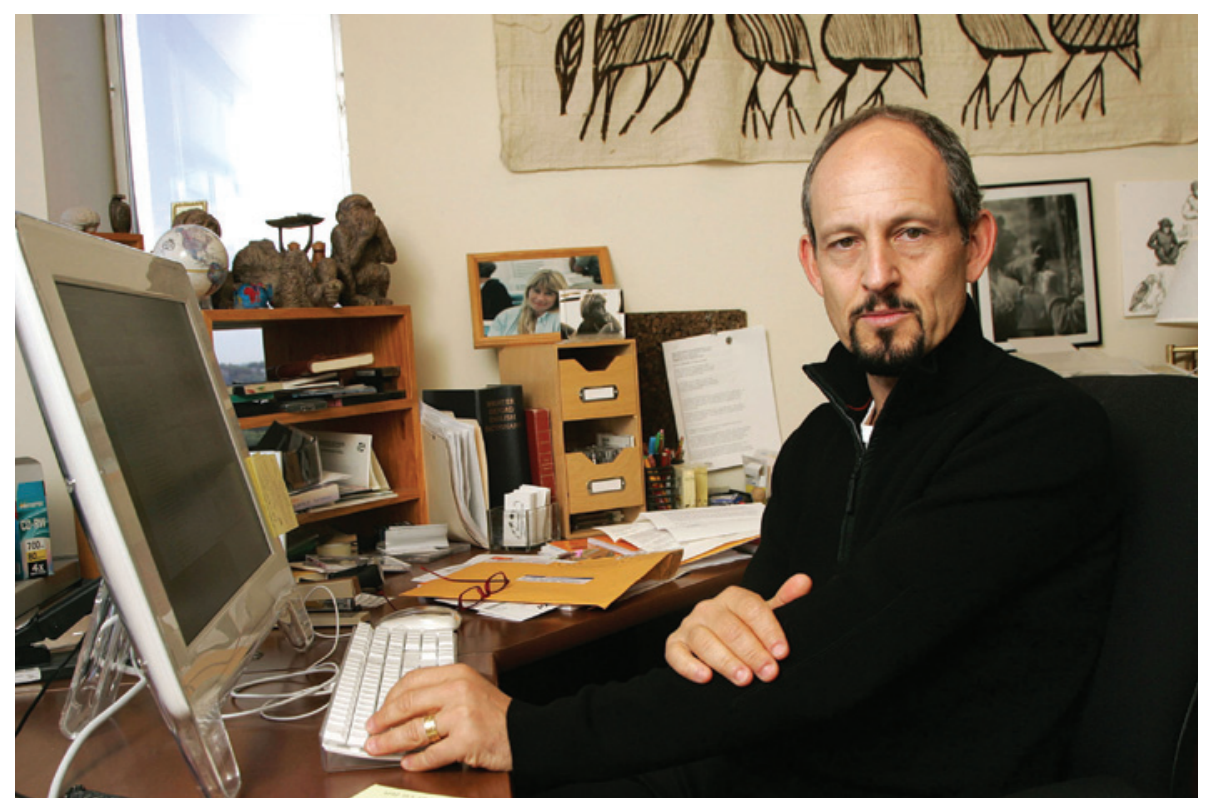

Marc Hauser left Harvard University in 2011 after the institution found him guilty of misconduct.

RESEARCH ETHICS

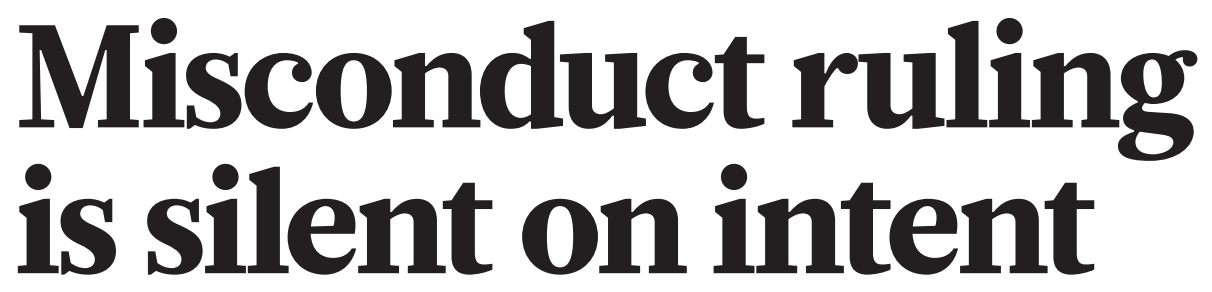

Psychologist Marc Hauser admits errors but not fraud.

\section{BY EUGENIE SAMUEL REICH}

M avens of research ethics often insist that there is a clear difference between sloppy science and scientific fraud. But if ever there was a case that blurs that line, it is that of Marc Hauser, a high-flying evolutionary psychologist who resigned from Harvard University in Cambridge, Massachusetts, in 2011, after the university found him guilty of misconduct.

In a finding published on 6 September in the Federal Register, the US Office of Research Integrity (ORI) in Rockville, Maryland, which oversees science funded by the National Institutes of Health (NIH), has also concluded that Hauser "engaged in research misconduct". The office found that he: "published fabricated data" in the journal Cognition in $2002^{1}$; "falsified" results in an unpublished study; and made false statements in four other instances. But the ORI did not state whether Hauser acted intentionally - its definition of misconduct also covers cases in which misrepresentations are "reckless".

That has provided enough wiggle room for both supporters and critics to claim the finding as a vindication. "It isn't a strong case for intentional misconduct. It seems it's peccadilloes," says Pierre Pica, a linguist at the French National
Center for Scientific Research in Paris, who has criticized the investigation. But Gerry Altmann, a psychologist at the University of York, UK, and editor-in-chief of Cognition, disagrees. "The number of instances [in the investigated body of work] suggests it is extremely unlikely it was not intentional," he says.

Harvard had found Hauser guilty of eight counts of misconduct in 2010, after a threeyear internal investigation of some of his studies of cognition in non-human primates. To the annoyance of many scientists, the university did not release its findings, so exactly what Hauser had done remained unclear. The ORI provides details on six counts of misconduct, three of which were published ${ }^{1-3}$.

In a statement sent to Nature, Hauser acknowledges mistakes and errors, but not scientific fraud or research misconduct, which the ORI says he neither admits nor denies. "Although I have fundamental differences with some of the findings in the ORI report," Hauser says, "I acknowledge that I made mistakes. I let important details get away from my control, and as head of the lab, I take responsibility for all errors made within the lab, whether or not I was directly involved." No one else who worked in Hauser's lab has been charged with misconduct. The ORI often resolves allegations 